\title{
AKTIVITAS ANTIOKSIDAN EKSTRAK IKAN GABUS (Channa striata) PADA TIKUS YANG DIINDUKSI DENGAN RIFAMPISIN- ISONIAZID
}

\author{
Andi Suhendi ${ }^{*}$, Fajrina Eka Puspa ${ }^{2}$, Hesti Pawarti ${ }^{3}$ \\ 1,2,3Fakultas Farmasi Universitas Muhammadiyah Surakarta \\ Jl. Achmad Yani, Tromol, Pabelan, Kartasura, Gatak, Pabelan, Sukoharjo, \\ Kabupaten Sukoharjo, Jawa Tengah 57162, Indonesia \\ Email: 1andi.suhendi@ums.ac.id, ${ }^{2}$ rinfidz@gmail.com, ${ }^{3}$ pawartihesti@gmail.com
}

Tanggal Submisi: 28April 2020; Tanggal Penerimaan: 2 Juni 2020

\begin{abstract}
ABSTRAK
Antioksidan merupakan substansi yang diperlukan untuk menetralisir radikal bebas dan mencegah kerusakan sel normal, protein, dan lemak. Radikal bebas berlebih dalam tubuh menyebabkan stres oksidatif. Salah satu parameter stres oksidatif adalah meningkatnya kadar malondialdehid (MDA). Ekstrak ikan gabus berperan sebagai antioksidan. Penelitian dilakukan untuk mengetahui efek pemberian suplemen ekstrak ikan gabus sebagai antioksidan pada tikus yang mendapatkan obat rifampisinisoniazid dosis tinggi. Tikus dikelompokan menjadi 4 yaitu kelompok I (kontrol), kelompok II (ekstrak ikan gabus), kelompok III (rifampisinisoniazid), dan kelompok IV (rifampisin-isoniazid dan ekstrak ikan gabus). Kadar MDA dalam darah diukur menggunakan metode Tiobarbiturat Acid Reactive Substance (TBARS) dengan spektrofotometer UV-Vis $532 \mathrm{~nm}$. Analisis data menggunakan uji Anava dan uji Kruskal Wallis. Hasil analisis kadar rata-rata MDA darah dan hati kelompok I, II, III, dan IV berturut-turut pada darah $0.67 \pm 0.12 ; 0.38 \pm 0.20 ; 4.01 \pm 1.57$; $2.68 \pm 1.72 \mu \mathrm{g} / \mathrm{mL}$, dan hati $3.73 \pm 0.80 ; \quad 2.96 \pm 1.94 ; 31.31 \pm 4.45$; $17.69 \pm 10.55 \mu \mathrm{g} / \mathrm{g}$. Hasil menunjukkan kadar MDA darah kelompok III dan IV signifikan terhadap kelompok II, pada hati kelompok III signifikan terhadap kelompok I dan II sedangkan kelompok IV signifikan terhadap kelompok I, II, dan III. Suplemen ekstrak ikan gabus dosis tinggi berpotensi sebagai antioksidan pada tikus yang mengalami stres oksidatif.
\end{abstract}

Kata kunci : Antioksidan, Ekstrak ikan gabus, MDA, Rifampisin, Isoniazid ISSN 1979-7621 (Print). ISSN 2620-7761 (Online)

\footnotetext{
ABSTRACT

Antioxidants are substances that needed to neutralize free radicals and prevent damage caused by free radicals to normal cells, proteins, and fats. Excessive free radicals in the body cause oxidative stress. One of the oxidative stress parameter is increased levels of malondialdehyde (MDA). Snakehead fish extract acts as an antioxidant. This study was conducted to
} 
determine the effect of snakehead fish extract supplement as an antioxidant in mice that received high dose rifampicin-isoniazid. The rats divided into 4 groups, group I (control), group II (snakehead fish extract), group III (rifampicin-isoniazid), and group IV (rifampicin-isoniazid and snakehead fish extract). MDA concentration were measured by with Tiobarbiturat Acid Reactive Substance (TBARS) UV-Vis spectrophotometer $532 \mathrm{~nm}$. Data analysis was performed using Anava tests and Kruskal Wallis test. The results of mean blood and liver MDA levels in groups I, II, III, and IV, respectively in blood $0.67 \pm 0.12 ; 0.38 \pm 0.20 ; 4.01 \pm 1.57 ; 2.68 \pm 1.72 \mu \mathrm{g} / \mathrm{mL}$, and liver $3.73 \pm 0.80 ; 2.96 \pm 1.94 ; 31.31 \pm 4.45 ; 17.69 \pm 10.55 \mu \mathrm{g} / \mathrm{g}$. The results showed that the blood in groups III and IV were significant in group II, in the liver group III was significant in group I and II, while in group IV it was significant in group I, II, and III. High dose of snakehead fish has potential as an antioxidant in rats that with oxidative stress.

Keywords: Antioxidant, Snakehead fish extract, MDA, Rifampicin, Isoniazid.

\section{PENDAHULUAN}

Ekstrak ikan gabus mengandung albumin yang berperan sebagai antioksidan melalui mekanisme sebagai pengikat radikal dan penangkapan ROS (Reactive Oxygen Species), sehingga tubuh akan membutuhkan antioksidan yang akan menjaga dari serangan radikal bebas dengan menghilangkan dampak negatif dari senyawa tersebut (Han dkk., 2004). Antioksidan adalah esensi yang diperlukan oleh tubuh untuk menetralkan dari serangan radikal bebas dan menahan kerusakan yang ditimbulkan oleh radikal bebas terhadap sel normal, protein, dan lemak (Depkes RI, 2007). Pada penelitian Widyaningsih dkk (2015), menyatakan bahwa penyebab timbulnya stres oksidatif dikarenakan adanya kerusakan jaringan yang diketahui dengan tingginya kadar MDA (Malondialdehyde). Stres oksidatif adalah suatu keadaan ketidakseimbangan yang serius antara penyusunan radikal bebas dan sistem antioksidan yang menimbulkan kerusakan jaringan yang potensial (Rosen dkk., 2002).

Salah satu obat yang yang digunakan sebagai anti tuberkulosis adalah isoniazid dan rifampisin. Penggunaan isoniazid dapat menyebabkan produksi ROS yang berlebih dan nitrogen yang reaktif akan diperparah dengan adanya rifampisin. Upaya untuk memperbaiki kesetimbangan radikal bebas, tubuh memiliki mekanisme meredam radikal bebas akan tetapi sangat terbatas. Sehingga penelitian ini diperlukan antioksidan dari luar. Salah satunya yang bisa digunakan adalah suplemen ekstrak ikan gabus (Channa striata), karena tubuh membutuhkan antioksidan untuk menjaga dari serangan radikal bebas (Wahyudi dan Soedarsono, 2015). Isoniazid dimetabolisme oleh enzim sitokrom P450 di hati menjadi senyawa Hydrazine dan Acetyl hydrazine. Kedua metabolit ini memicu produksi ROS secara berlebih yang menyebabkan mekanisme homeostatis 
di hati yang akan terganggu akibat keadaan stres oksidatif. Pada metabolit rifampisin 3-formyl rifampicin menambah efek toksik di hati karena meningkatkan aktivitas enzim sitokrom $\mathrm{P} 450$, sehingga metabolit isoniazid menyebabkan ROS yang berlebih sehingga tidak mampu dikendalikan oleh antioksidan endogen, akibatnya terjadi peroksidasi lipid yang berujung pada kematian sel hati (Kumar dan Ramesh, 2014). MDA merupakan hasil akhir dari peroksidasi lipid dan telah digunakan sebagai biomarker terjadinya kerusakan di hati akibat stres oksidatif (Nathiya dkk., 2016).

\section{METODE PENELITIAN}

Penelitian ini adalah penelitian eksperimental dengan pre and post-test design menggunakan rancangan acak lengkap (RAL) dengan 4 kelompok perlakuan. Protokol penelitian sudah memenuhi ethical clearance (No. 1952/A.1/KEPK-FKUMS/II/2019).

Sebelum dilakukan perlakuan, hewan diletakkan di dalam kandang yang telah disiapkan dan diberi pakan secara normal selama 1 pekan sebagai masa adaptasi. Hewan uji dibagi menjadi 4 kelompok secara acak, 1 kelompok terdiri dari 3 ekor hewan uji.

Hewan uji yang telah diaklimatisasi dibagi menjadi 4 kelompok:

a. Kelompok I (kontrol normal) diberikan perlakuan berupa pakan terstandar dan minum secara normal selama setiap hari.

b. Kelompok II diberikan perlakuan berupa pakan terstandar dan minum secara normal dan suplemen ekstrak ikan gabus secara per oral dengan dosis $54 \mathrm{mg} / 200 \mathrm{gBB}$. c. Kelompok III diberikan rifampisinisoniazid $100 \mathrm{mg} / 200 \mathrm{gBB} / \mathrm{hari}$ secara per oral.

d. Kelompok IV diberikan ransum makanan secara normal, rifampisinisoniazid $100 \mathrm{mg} / 200 \mathrm{gBB} / \mathrm{hari}$ serta suplemen ekstrak ikan gabus secara per oral dengan dosis 54 $\mathrm{mg} / 200 \mathrm{gBB}$.

Perlakuan dilakukan setiap hari selama 14 hari, setiap 7 hari dilakukan pengamatan fisik berupa penimbangan perubahan berat badan.

\section{Pengukuran Malondialdehid (MDA)}

Data yang didapatkan dianalisis homogenitas dan distribusi data diketahui bahwa distribusi data perubahan kadar MDA darah dan hati tikus tidak normal, signifikansi $<0,05$ maka dari itu digunakan analisis statistik non parametrik (Sujarweni, 2015). Sehingga dilakukan analisis signifikansi data menggunakan uji Post Hoc-LSD (Least Significant Difference).

\section{Bahan}

Bahan yang diperlukan untuk pembuatan dan pengujian antioksidan ekstrak ikan gabus (Channa striata) pada hewan uji tikus antara lain: ekstrak ikan gabus (Channa striata) didapatkan dari CV. Herbal Nusantara dengan dosis $54 \mathrm{mg} / 200 \mathrm{gBB}$, tablet isoniazid dan kapsul rifampisin dosis rifampisin-isoniazid $100 \mathrm{mg} / 200 \mathrm{gBB}$ didapatkan dari Apotek Akmal Sehat, reagen TCA $15 \%$, TBARS, asam asetat, PBS, CMC-Na, aquadest dan tisu didapatkan dari Laboratorium Farmakologi Fakultas Farmasi Universitas Muhammadiyah Surakarta.

Hewan uji yang digunakan adalah tikus putih jantan galur Wistar (Rattus norvegicus) sebanyak 12 ekor 
(berat badan tikus sebesar 150-200 gram dengan umur 2-3 bulan) yang diperoleh dari Laboratorium Farmakologi Fakultas Farmasi Universitas Muhammadiyah Surakarta.

\section{HASIL DAN PEMBAHASAN}

Rifampisin-isoniazid dosis tinggi akan menghasilkan radikal bebas. Radikal bebas tersebut dapat bereaksi dengan PUFA (Polyunsaturated Fatty Acid) sehingga membentuk metabolit sekunder berupa aldehid (MDA) (Hodgson dan Levi, 2000). Tubuh membutuhkan antioksidan untuk menjaga dari serangan radikal bebas dengan menghilangkan dampak negatif dari senyawa toksik (Han dkk., 2004).

Parameter MDA digunakan untuk hasil akhir dari peroksidasi lipid dimana sebagai biomarker terjadinya kerusakan di hati akibat stres oksidatif (Nathiya dkk., 2016). Hal ini disebabkan karena adanya kandungan senyawa asam lemak tidak jenuh rantai panjang $(\mathrm{PUFA}=$ Polyunsaturated Fatty Acid) yang mudah teroksidasi dan menghasilkan produk oksidasi, salah satunya MDA. Pengukuran kadar MDA menggunakan metode TBARS. Proses peroksidasi lipid yang diperantarai oleh radikal bebas menghasilkan senyawa MDA (Nayanatara dkk., 2005). Prinsip kerja dari pengukuran MDA adalah reaksi satu molekul MDA dengan dua molekul asam tiobarbiturat (TBA) membentuk warna merah muda yang diukur pada spektrofotometer dengan panjang gelombang $532 \mathrm{~nm}$ (Yagi, 1994). MDA juga digunakan sebagai timbulnya stres oksidatif karena adanya kerusakan jaringan yang ditandai dengan meningkatnya kadar MDA (Widyaningsih dkk., 2015).

Penggunaan isoniazid dan rifampisin menyebabkan cedera hati yang lebih signifikan, peningkatan produksi MDA menyebabkan penurunan status antioksidan. Isoniazid meningkatkan ekspresi protein CYP2E1 hepatik dan isoniazid/rifampisin (dalam kombinasi) menurunkan ekspresi CYP1A2 hepatik. Penelitian dari (Lian dkk., 2013) dengan jelas menunjukkan bahwa pemberian isoniazid dan rifampisin pada hepatosit, CYP2E1, dan CYP1A2 yang terlibat dalam patogenesis isoniazid dan rifampisin yang diinduksi, tidak menghasilkan metabolit yang bersifat hepatotoksik ataupun metabolit yang memicu alergi, sehingga proses eliminasi hydrazine menjadi berkurang (Lian dkk., 2013).

Hati merupakan organ dimana proses metabolisme terjadi, dan memiliki mekanisme detoksifikasi. Detoksifikasi ini melibatkan antioksidan endogen seperti glutation transferase, katalase, dan sistem superoksida dismutase (SOD). Glutation transferase, terutama gutation-s-transferase (GTS) berperan dalam pengeleminasian hydrazine. Namun isoniazid dan hydrazine bersifat menginhibisi CYP1A2 yang terlibat dalam proses detoksifikasi, 2A6, 2C19 dan 3A4 yang akan terjadi penurunan sintesis glutation. Penurunan sintesis glutation mengakibatkan naiknya sintesis malondialdehid yang merupakan parameter terjadinya stres oksidatif akibat ketidakseimbangan oksidan dan antioksidan. (Huang dkk., 2003; Tostmann dkk., 2007).

Data dari nilai kadar MDA pada tikus setelah diinduksi rifampisin- 
isoniazid dan ekstrak ikan gabus hewan uji $(n=3)$ tersaji pada Tabel 1. (Channa striata) serta berat badan

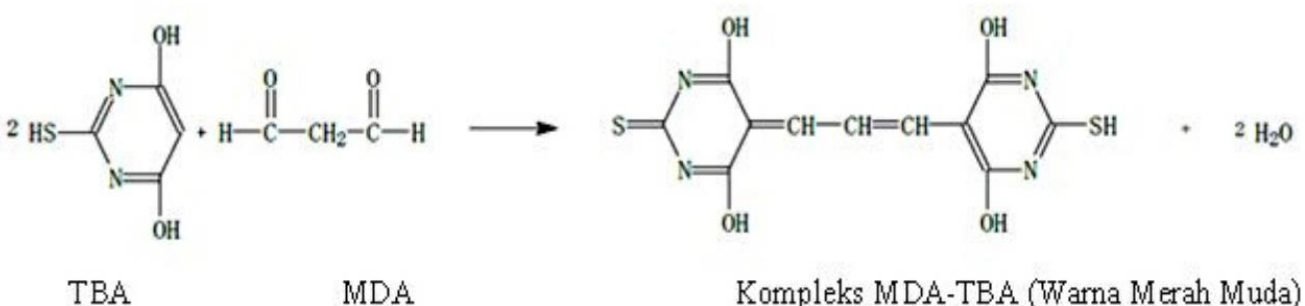

Gambar 1. Reaksi Pembentukan Senyawa Kompleks MDA-TBA (Nawar dkk., 1985)

Tabel 1. Kadar Malonaldehid (MDA) dalam Darah dan Hati serta Berat Badan Hewan Uji (N=3)

\begin{tabular}{|c|c|c|c|c|}
\hline Hari & Kelompok & $\begin{array}{c}\text { MDA } \\
\text { Darah }(\mu \mathrm{g} / \mathrm{mL})\end{array}$ & $\begin{array}{c}\text { MDA } \\
\text { Hati }(\mu \mathrm{g} / \mathrm{g})\end{array}$ & $\begin{array}{c}\text { Berat Badan } \\
\text { (g) }\end{array}$ \\
\hline \multirow{4}{*}{$\begin{array}{l}\text { Baseline } \\
\text { (hari ke-0) }\end{array}$} & I & $0.51 \pm 0.47$ & \multirow[t]{4}{*}{ - } & $195 \pm 30$ \\
\hline & II & $0.74 \pm 0.56$ & & $190 \pm 10$ \\
\hline & III & $0.89 \pm 0.67$ & & $169 \pm 20$ \\
\hline & IV & $1.17 \pm 0.60$ & & $174 \pm 33$ \\
\hline \multirow[t]{4}{*}{ Hari ke-7 } & I & $0.67 \pm 0.37$ & \multirow[t]{4}{*}{ - } & $215 \pm 26$ \\
\hline & II & $0.49 \pm 0.28$ & & $208 \pm 8$ \\
\hline & III & $3.17 \pm 1.02$ & & $149 \pm 10$ \\
\hline & IV & $1.84 \pm 0.75$ & & $170 \pm 21$ \\
\hline \multirow[t]{4}{*}{ Hari ke-14 } & I & $0.67 \pm 0.12$ & $3.73 \pm 0.80$ & $232 \pm 31$ \\
\hline & II & $0.38 \pm 0.20$ & $2.96 \pm 1.94$ & $240 \pm 18$ \\
\hline & III & $4.01 \pm 1.57 *$ & $31.31 \pm 4.45 * *$ & $168 \pm 7$ \\
\hline & IV & $2.67 \pm 1.72 *$ & $17.69 \pm 10.55^{* * / * * *}$ & $159 \pm 13$ \\
\hline
\end{tabular}

*signifikan terhadap kelompok II, **signifikan terhadap kelompok I dan II, ***signifikan terhadap kelompok III

Kadar MDA pada tikus setelah diinduksi rifampisin-isoniazid dan pemberian uji ekstrak ikan gabus (Channa striata) dapat dilihat pada Gambar 2. Berdasarkan data Gambar 2 dan Tabel 1, pada kelompok kontrol (I) terjadi penurunan, kontrol tidak mendapatkan intervensi yang hanya pakan dan minum terstandar sehingga kadar MDA dari kelompok kontrol dianggap sebagai kadar normal dari parameter hewan uji.

Kelompok II (mendapatkan ekstrak ikan gabus) mengalami penurunan nilai kadar MDA pada darah, hati, dan peningkatan berat badan. Kelompok II yang hanya menerima asupan ekstrak ikan gabus dimana sebagai aktivitas antioksidan atau kontrol normal sehingga tidak terjadi peningkatan nilai kadar MDA.

Data pada kelompok III (mendapatkan rifampisin-isoniazid) menunjukkan bahwa nilai kadar MDA pada darah, hati, dan peningkatan berat badan.

Kelompok IV terjadi kenaikan nilai kadar MDA darah dan hati 
signifikan $(\mathrm{p}<0,05)$ dan penurunan hati sehingga disimpulkan bahwa obat berat badan. Kenaikan MDA dan rifampisin-isoniazid mempengaruhi penurunan berat badan yang signifikan kadar MDA karena memiliki nilai dikarenakan adanya kerusakan pada sel kadar MDA yang tinggi.

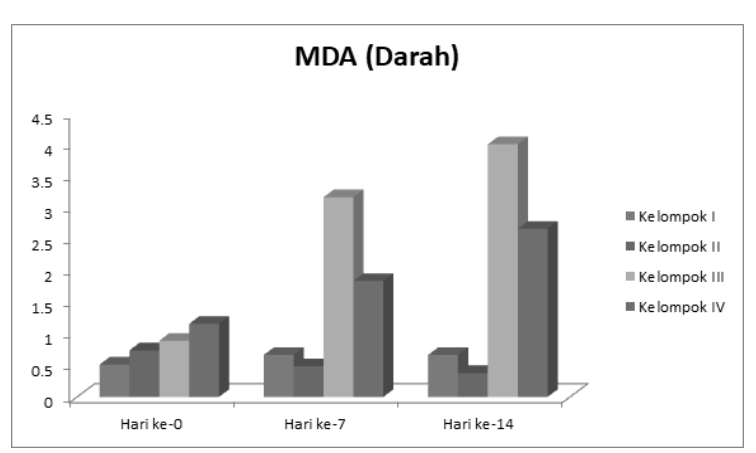

(a)

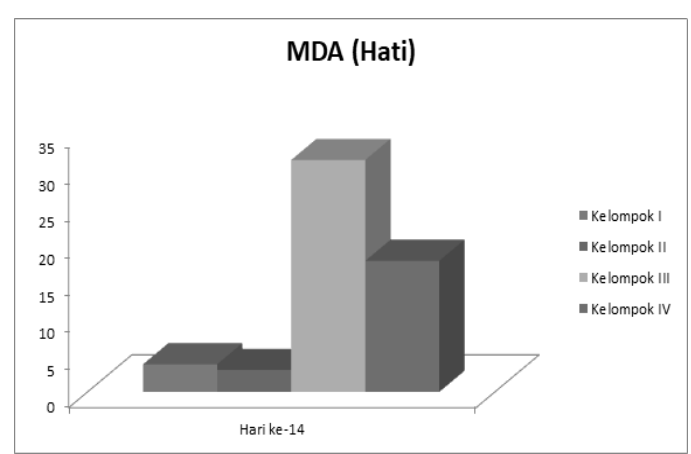

(b)

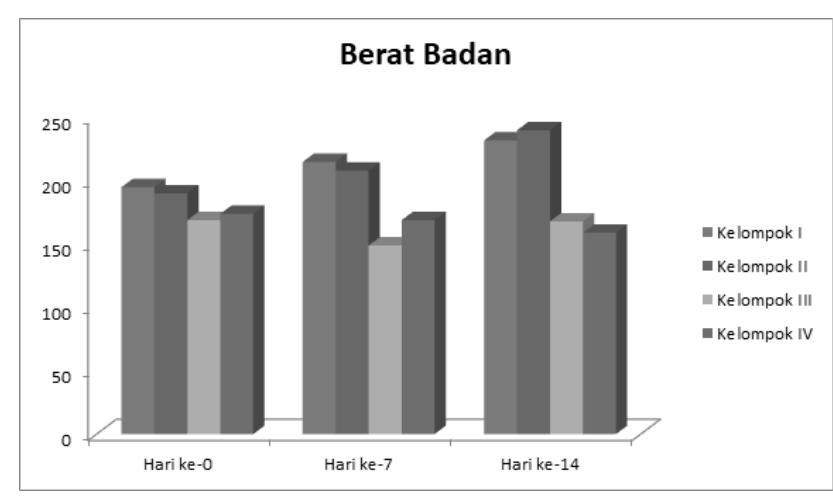

(c)

Gambar 2. Kadar MDA Darah $(\mu \mathrm{g} / \mathrm{mL})$ dan Hati $(\mu \mathrm{g} / \mathrm{g})$ dan Berat Badan $(\mathrm{g})$

Gambar a:

Kelompok III yang mendapatkan obat rifampisin-isoniazid mengalami kenaikan kadar MDA yang signifikan terhadap kelompok yang lain (p-value : $0.05<0.05$ ). Kadar MDA merupakan parameter untuk menunjukkan adanya kerusakan sel pada hati.

Gambar b:

Kelompok I dan II memiliki nilai MDA yang rendah, sedangkan kelompok III dan IV mengalami kenaikan MDA merupakan parameter yang menunjukkan adanya kerusakan sel pada hati.
Gambar c:

Kenaikan berat badan hewan uji normal terjadi saat bertambahnya usia. Kenaikan berat badan dapat terjadi karena energi dari proses anabolisme > katabolisme. Kelompok kelompok I, II, dan IV mengalami kenaikan berat badan yang stabil sedangkan kelompok III berat badan hewan uji tidak stabil karena energi dialihkan untuk melakukan regenerasi pada sel yang rusak. 
Keterangan pada Gambar 2:

Kelompok I : Pakan + minum.

Kelompok II : Suplemen ekstrak ikan gabus secara per oral dengan dosis 54 $\mathrm{mg} / 200 \mathrm{mgBB}$.

Kelompok III : Rifampisin-Isoniazid $100 \mathrm{mg} / 200 \mathrm{mgBB} / \mathrm{hari}$ secara per oral.

Kelompok IV : Rifampisin-Isoniazid $100 \mathrm{mg} / 200 \mathrm{mgBB} / \mathrm{hari}$ serta suplemen ekstrak ikan gabus secara per oral dengan dosis $54 \mathrm{mg} / 200 \mathrm{mgBB}$.

Data pada kelompok IV (mendapatkan rifampisin-isoniazid dan ekstrak ikan gabus) terjadi peningkatan kadar MDA dan penurunan berat badan. Peningkatan kadar MDA dikarenakan adanya kerusakan pada sel hati namun mendapatkan asupan aktivitas antioksidan (ekstrak ikan gabus) sehingga efek dari obat rifampisin-isoniazid dapat dikurangi. Hal ini bisa diketahui dengan membandingkan nilai kadar kelompok IV dengan kelompok III. Peningkatan kadar MDA, menandakan peningkatan peroksidasi lipid yang menyebabkan kerusakan jaringan dan ketidakberhasilan mekanisme pertahanan antioksidan untuk mencegah pembentukan radikal bebas yang banyak. Sistem antioksidan hati juga dipengaruhi melalui degradasi peroksidasi lipid dari bio-membran, yang merupakan penyebab utama hepatotoksisitas (Joshi dkk., 2015).

Hasil uji statistik menunjukkan bahwa kelompok III mengalami kenaikan MDA secara signifikan ( $\mathrm{p}<$ 0.05 ) dibandingkan yang mendapatkan perlakuan: artinya ada hasil berbeda antara kontrol, yang mendapatkan ekstrak ikan gabus terhadap kontrol positif yang hanya mendapatkan obat rifampisin-isoniazid.

Penelitian
Santoso (2009), menunjukkan ekstrak ikan gabus terbukti mempunyai aktivitas antioksidan pada tikus yang menggunakan obat parasetamol. Aktivitas antioksidan dari ekstrak ikan gabus diujikan untuk dilihat aktivitasnya sebagai antioksidan akibat pemberian rifampisin dan isoniazid.

Kandungan albumin dan $\mathrm{Zn}$ yang ada dalam ekstrak ikan gabus berfungsi sebagai antioksidan. Antioksidan mampu menangkal radikal bebas masuk dalam NAPQI yang didapatkan dari metabolisme parasetamol dosis tinggi. Hal ini selaras dengan hasil penelitian ini dimana ekstrak ikan gabus mampu berfungsi sebagai antioksidan yang dinilai dari nilai kadar MDA dan berat badan tikus pada kelompok II dan IV.

Berdasarkan penjelasan di atas, dapat disimpulkan bahwa asupan ekstrak ikan gabus merupakan asupan yang penting yang harus diterima pasien untuk meringankan efek samping dari obat rifampisin-isoniazid bagi pasien dengan penyakit hati. Ekstrak ikan gabus merupakan asupan yang paling mudah didapatkan karena berasal dari bahan pangan yang memiliki kandungan albumin yang berfungsi sebagai antioksidan dan juga dapat berfungsi untuk memperbaiki kerusakan sel hati.

\section{KESIMPULAN}

Pemberian ekstrak ikan gabus dengan dosis $54 \mathrm{mg} / \mathrm{kgBB}$ secara peroral pada tikus dapat menurunkan kadar MDA pada darah dan hati dibandingkan kelompok yang hanya mendapatkan rifampisin-isoniazid dengan dosis masing-masing 100 $\mathrm{mg} / \mathrm{kgBB}$. 


\section{UCAPAN TERIMAKASIH}

Ucapan terima kasih kepada CV.

Herbal Nusantara Karanganyar dan
PT. Mega Medica Pharmaceutical atas dukungan dana penelitian ini.

\section{DAFTAR PUSTAKA}

Adnyana I.K. \& Sigit J.I. (2012). Effect of Administration Effect of Cork Fish (Channa striata) Concentrate to The Blood's Profile of Balb/Mouse Thrombocytopenia Model. Medika Planta Research, 2(1): 13-25.

Departemen Kesehatan Republik Indonesia. (2007). Pedoman Nasional Penanggulangan Tuberkulosis, DirJen P2M-PL Departemen Kesehatan, Jakarta.

Han, S.S., Lo, S.C., Choi, Y.W., Kim, J.H. \& Baek, S.H. (2004). Antioxidant Activity of Crude Extract and Pure Compounds of Acer ginnala Max. Bull Korean Chem Soc., 25(3): 389.

Hodgson E. \& Levi, P.E. (2000). A Textbook of Modern Toxicology, McGraw-Hill Companies, New York.

Joshi, B.C., Atish, P. \& Ajudhia, N.K. (2015). Hepatoprotective potential of antioxidant potent fraction from Urtica dioica Linn. (whole plant) in $\mathrm{CCl}_{4}$ challenged rats, Toxicology Reports, 2, 1101-1110.

Nathiya, S., Rajaram S. \& Philips A. (2016). Hesperidin alleviates antitubercular drug induced oxidative stress inflammation and apoptosis in rat liver. International Journal of Biomedical Research, 7(7): 439-446

Nawar, W.W. (1985). Lipids. In: Food Chemistry. O. R. Fennema (ed.). pp.139244, Marcel Dekker, Inc., New York.

Nayanatara, A.K., Nagaraja, H.S. \& Anupama, B.K. (2005). The Effect of Repeated Swimming Stress on Organ Weights and Lipid Peroxidation in Rats. Thai Journal of Physiological Sciences, 18(1).

Rose, M.H., P.N, Sudha \& Sudhakar, K. (2018). Effect of Antioxidants and Hepatoprotective Activities Of Methanol Extract of Beet Root (Beta vulgaris L.) Against Carbon Tetrachloride Induced Hepatotoxicity in Rats Models. International Journal of Pharmaceutical Sciences and Research, 5(6): 2536-2545.

Rosen, P., Tritschler, H. J., \& Packer, L. (2002). Handbook of Vascular Complications in Diabetes: Mechanisms and the Influence of Antioxidants, Second Edition, Revised and Expanded, New York. Santoso, Agus, H., 2009, "Uji Potensi Ekstrak Ikan Gabus (Channa striata) Sebagai Hepatoprotektor pada Tikus yang Diinduksi dengan Parasetamol”, Thesis, Institut Pertanian Bogor, Bogor. 
Tawali, A.B., Mathelda, K.R., Meta, M. \& Suryani. (2012). Difusi Teknologi Produksi Konsentrat Protein dari Ikan Gabus sebagai Food Supplement di Jayapura. Prosiding InSINas. 0201, 243-247.

Tostmann A., Boeree M.J., Aarnoutse R.E., Lange W.C.M. De, Ven A.J.A.M. Van Der \& Dekhuijzen R. (2007). Antituberculosis drug-induced hepatotoxicity: Concise up-to-date review, Journal of Gastroenterology and Hepatology, 23, 192-202.

Wahyudi, A.D. \& Soedarsono. (2015). Farmakogenomik hepatotoksisitas obat anti tuberkulosis, Departemen Pulmonologi dan Ilmu Kedokteran Respirasi, Fakultas Kedokteran Universitas Airlangga/RSUD Dr. Soetomo, 1, 1-6.

Widyaningsih, Wahyu., Riza, S. \& Indra, P. (2015). Efek antioksidan ekstrak etanol ganggang hijau (Ulva lactuca L.) terhadap kadar malondialdehid (MDA) dan aktivitas enzim superoksida dismutase (SOD) hepar tikus yang diinduksi $\mathrm{CCl}_{4}$. Media Farmasi, 12(2): 163-175. 